\title{
DUTCH AND FLORIDA PRACTICES ON REVETMENT DESIGN
}

F. Gerritsen and P. Bruun

Rijkswaterstaat, Holland and University of Florida

\section{INTRODUCTION}

In this paper the authors discuss Dutch and Florida practices on revetment design. Instead of presenting two different papers they have preferred to prepare one paper in which basic principles and techniques are emphasized.

\section{DESIGN CRITERIA FOR SEASHORE REVETMENTS}

In designing revetments the following factors should be considered:

\section{THE EROSION SITUATION AND THE NEED FOR ARTIFICIAL NOURISHMENT}

Before a revetment is to be built the stability conditions of the beach or shore should be carefully evaluated. In some instances the shoreline may be subject to strong periodic variations making it advisable to build the revetment at a certain safe distance from the water line. In other cases, measures against erosion such as groins and artificial nourishment may be necessary before the construction of a revetment is started or in conjunction herewith.

In considering shoreline stability it should be realized that this stability is of dynamic nature. A beach or shore may be stable and still show important seasonal or periodic variations; for this reason the period over which shoreline behavior is studied before the construction of a revetment should be long enough to obtain proper conclusions. A misevaluation of the situation may lead to high cost of repair or even the necessity of complete abandonment of the revetment (1).

In order to arrive at proper data, the area of study should be large enough to determine cyclic coastal processes and to study the influence on the area for which a revetment is considered.

If the pertinent area appears to be subject to gradual erosion, artificial nourishment should be considered. In the last decades experiences on a number of artificial nourishment projects in the United States have shown that this method can be very successful provided the project is carried out with the necessary preparation and know how.

If artificial nourishment is not economically or technically feasible, other measures such as the construction of certain types of groins or - in special cases - the building of a jetty may be justified, but only after a very thorough study of the consequences of such works.

When residential sections or other valuable property are to be protected the revetment may have to be located where it provides the required protection. Situations may occur where occasional bank or dune erosion is restored by natural processes; in such cases the building of a revetment may not be necessary or it should be postponed. 


\section{OFFSHORE BEACH PROFILE}

In connection with the above section, offshore beach profiles may be indicative of the type of coastal processes that are at stake. In this respect, we may distinguish between sufficiently nourished, undernourished and overnourished offshore profiles(2).

One should particularly be careful if a deep trough is continuously found between the beach and the offshore bar. In this trough, high velocities may occur occasionally thereby adversely affecting beach stability by rapid shoreline fluctuations.

\section{SOIL CONDITIONS}

Soil conditions of the beach and foreshore affect littoral drift processes. For the proper choice of material for artificial nourishment, average grain size and grain size distribution of the sand are important.

The permeability ( $k$-value) and the silt content of the soil determine soll condition of the bank or dune. The latter are of importance for the technical design of the structure.

A high degree of permeability facilitates elimination of differences in pore water pressure and is, therefore, beneficial to a high degree of soil stability.

The presence of silt particles reduces the permeability. Thin, horizontal layers of clay prevent water flow in vertical direction. They may, therefore, have an adverse influence on revetment stability.

\section{DES IGN WATER IEVEL}

It is a well known fact that during storm a nd hurricane conditions the water table along the coast line may rise to a level, that is considerably higher than ordinary spring tide conditions.

The problem of extreme high tides has been subject of thorough studies, both in the United States and in Western Europe. The results of these studies can be used as a basis for the design.

A few characteristics may be mentioned here:

The analysis of the height of storm tides on a frequency basis was developed in the Netherlands in 1939 by P. J. Wemelsfelder (3). He showed that for the open Dutch sea coast high tide data plotted in a cumulative frequency diagram presented a linear relationship if a semi-logarithmic diagram was used. Recent studies on Dutch conditions by Wemelsfelder and others (4) have confirmed the applicability of Wemelsfelder's original idea. Although slightly different diagrams were obtained in case all high tide data or a selected group (e.g. associated with dangerous storms) was used the original conception remained the same.

In studying storm tides in Florida (5), it was found that such single linearity for a11 data could not always be maintained. It appeared that for 
the Florida coast high tide data associated with tropical storms (hurricanes) and those associated with regular storms followed different frequency distributions. Treatment of the data was based on the hypothesis that the two groups of data are homogeneous in themselves but nonhomogeneous with respect to one another.

Fig. 1 shows a few selected frequency curves for tide elevations on Florida's East Coast in which the above mentioned characteristics are shown.

The level that is to be selected for the design of a revetment not only depends on the characteristics of the frequency diagram but also on the value of the property that is to be projected.

If large areas of valuable low lying lands are involved design criteria must respect that. of this.

Certain seawalls on the Dutch North Sea coast may be seen as an example

In Holland the Delta dikes are based on a design water level whereby the probability that such leve1 is equaled or exceeded amounts to $1 \%$ per century.

Determination of the proper design level is an economic decision problem; an insight into this can be obtained by considering the variation in the coast on costruction and damage (maintenance) that may be expected with an assumed design level. Reference is made to (4) and (5).

The higher the value of the area to be protected, the higher the design water level that is to be chosen as a basis for revetment design.

\section{DESIGN WAVE}

The design wave is strongly dependent upon the design water level that has been chosen. The height of the water table and the type of wave conditions constitute two essential boundary conditions for revetment design.

Sometimes one is fortnnate enough to have measured wave data in the vicinity of the study area. If the period of wave observation is long enough analysis of the data will provide broad information on wave characteristics from which the design wave can be derived. One should be sure, however, that wave data during storms or hurricanes is included in the recording so as to draw the right conclusions.

Usually it will also be required to consider the changes in wave characteristics that take place during the passage of the waves from the observation post to shore.

Particularly if large shoal areas are to be passed wave height and wave period may be reduced considerably, whereby the height of the tide may play a decisive role.

With respect to waye direction, wave refraction should be considered.

In other instances wave data of the required degree of accuracy may not be available from observations. In such case, computations have to be made 

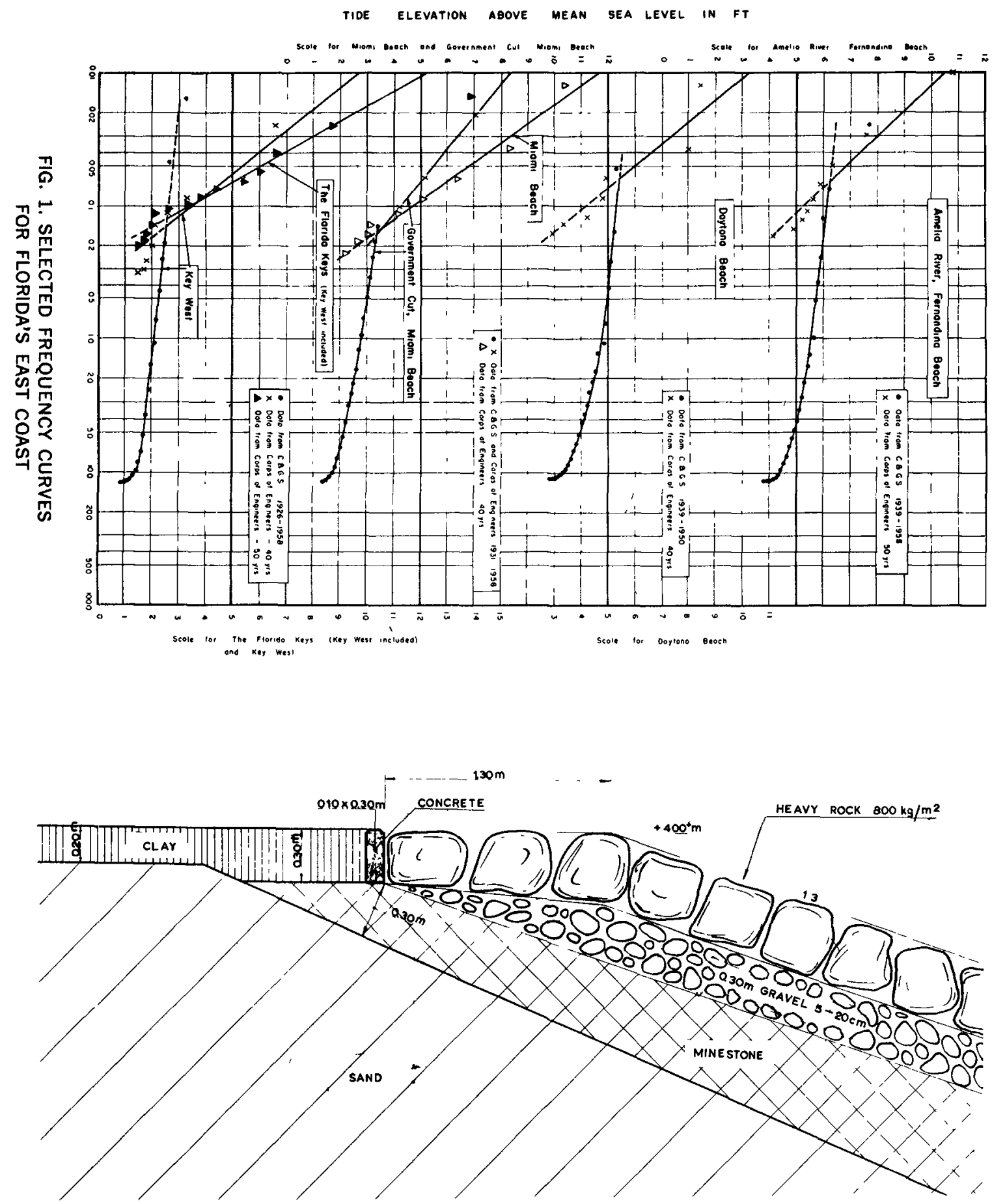

FIG. 2. ROCK REVETMENT WITH FILTER LAYERS OF GRAVEL AND MINESTONE 
based on wind and tide data. Reference is made to the studies of Bretschneider (6) and Wilson (7).

For practical design purposes wave analyses can be limited to determining a certain maximum design wave height and period where the wave height is a function of the offshore bottom geometry and deep water wave characteristics. Overtopping may be permitted with a minor frequency only.

Weather observations or computations provide wave data. In both cases, the influence of foreshore configuration on wave characteristics may be considerable, so that approaching waves change direction and may be significantly reduced or increased in height.

\section{WAVE ATTACK, WAVE UPRUSH AND WAVE REFLECTION}

Water level and design wave conditions will determine the type of revetment heavy, medium or light - that will be required. From model experiments we may conclude that wave attack is usually heaviest on that part of the slope that lies just below the (average) water table. We cannot exclusively determine, however, what type of blocks (weight, shape) will be required on various parts of the slope: there is still no well established relationship between the characteristics of the waves and the type of construction to be preferred. Conclusions on the type of construction will remain difficult, also in the future, because the strength of a revetment also depends on accuracy of construction, deviations in size of stone or block, width of joints, type of filter, etc

In a few cases, e.g. for asphalt revetment a theoretical evaluation of revetment dimension, in view of given wave condition, is possible (8).

Numerous hydraulic experiments have been carried out on revetments, partici larly on wave uprush both in the U.S.A. and in Europe, in later years also in Japan. It has been shown that wave uprush can be reduced by decreasing the outer slope of the revetment, by increasing its permeability or roughness (e.g. by roughness elements of various types) or by the use of a berm. The berm may be gently sloping towards the sea or it may be carried out as a stilling basin sloping towards the backland or backslope. Reference is made to work by Bruun (9) to the studies of the Delft Hydraulics Laboratory (10) and of the Beach Erosion Board (11).

Measures that limit wave uprush usually also limit wave reflection: the smaller the value of the outer slope and the higher the permeability, the lesse1 also the wave reflection. Heavy backrush may have an adverse influence on the beach in front of the wall and it has been found that roughness elements may be beneficial in limiting erosion at the toe.

On a seashore, economy may often call for simplicity rather than for top performance hydraulically speaking. Complicated block geometry increases costs of manufacturing and placings of blocks. Uprush and backwash may be reduced somewhat but it is cheaper to build the revetment a little higher or to reduce the slope slightly.

If the revetment is not high enough wave uprush may cause overtopping. This may be very dangerous; besides scour and accompanying loss of stability may occur due to saturation of the soil. To prevent this a wave screen may be 
helpful for certain conditions. Adequate drainage of the soil behind the revetment is, therefore, indispensable.

\section{HYDRAULIC PRESSURES UNDERNEATH IMPERMRABLE REVETMENTS}

Impermeable revetments such as asphalt revetments or bitumen grouted stor pitchings may be subject to hydraulic pressure forces. They are a major factc in the design. During high storm tides of long duration water may enter into the soil behind the revetment and due to a phase difference in water pressure outside and inside the revetment hydraulic pressures may be exerted from withi on the tructure. In various cases these forces have been a source of failure and it is, therefore, very essential that these pressure differences be known. Permeability variations in the subsoil and possibly in a pervious toe construc tion will change the magnitude of the lifting forces so that for a good desigr a relatively large number of computations has to be carried out.

For this type of computations an electric analog computer of rather simpl construction can be used (12). It is based on the similarity between Darcy's law (ground water) and Ohm's law (electricity). It consists of a plate conduc in the shape of the dike or seawall. The water storage capacity of the ground is simulated by electric capacitors.

Electric tensions simulate the piesometric level underneath the revetment

\section{DUTCH PRACTICE}

Two main types of revetments can be distinguished: permeable and impermea ones.

The permeable types have an "open" surface whereby water may flow into an out of the structure. The impermeable types prevent water to flow through the structure, so that hydraulic pressures may build up behind it. Such pressure forces are important factors in the design.

The permeable types require one or more layers of filter material to reta the soil particles. The filter should be open enough to eliminate hydraulic pressure differences and at the same time dense enough to prevent soil particl from being washed out.

Regarding the permeable or open revetments the following principal types can be considered:

Open filter revetments

Stone pitching

Concrete block revetments

Copper-slag block revetments

Concerning the impermeable types we will distinguish:

Bitumen grouted stone, block or slab revetments

Asphalt reyetments 


\section{OPEN FILTER REVETMENT}

The open filter revetment consists of a few layers of filter material of different size covered by one or more layers of rock or rubble.

Filter characteristics are determined by the fineness of the subsoil on one hand and by the wave forces on the structure on the other hand.

The weight of the individual rock or rubble, forming the top layer has to be in accordance with wave forces to be expected.

From the top layer downward the size and distribution of stone, gravel or sand of various filter layers may rapidly decrease. The requirements of stability are that finer particles do not move into the zones of the bigger ones.

In designing such filters advantage can be taken from filter requirements that are being used for water supply system (13), for which the following general criteria hold:

(a) The material used for the filter must be more pervious than the material of the subsoil in order to avoid excessive hydraulic pressures.

(b) The volume of pores of the filter material must be sufficiently sma11 in order to prevent soil particles to penetrate into and stop up the filter layers.

(c) The thickness of the layer must be big enough to ascertain an adequate grain size distribution across the layer.

Design criterla for filter revetments can never be fully the same; however, a basic indication on the size of the stones or particular on the successive layers may be obtained.

In particular the third requirement will usually not hold for the top layer of heavier stones.

In areas exposed to limited wave action such filter construction may exis of a layer of 6" sand grave1 $0.5-5 \mathrm{~mm}$, on which a 14" layer grave1 $30-80$ II and covered by basalt rock of $10-80 \mathrm{lbs}$ to the amount of $750 \mathrm{lbs}$ per square feet.

Another example of such construction is the use of mine stone (waste material from mines) as filter material (Fig. 2). This structure located in an estuary is exposed to light to heavy waves. The top layer consists of basalt rock of $160-400 \mathrm{lbs}$.

It is interesting to compared Dutch filter revetmentswith similar structures such as applied in Florida.

The basic principles of design are the same. In some Florida structures one or more filter layers have been replaced by synthetic filter sheets.

The weight of the individual blocks of the top layer should be in accordance with wave forces to be expected. 


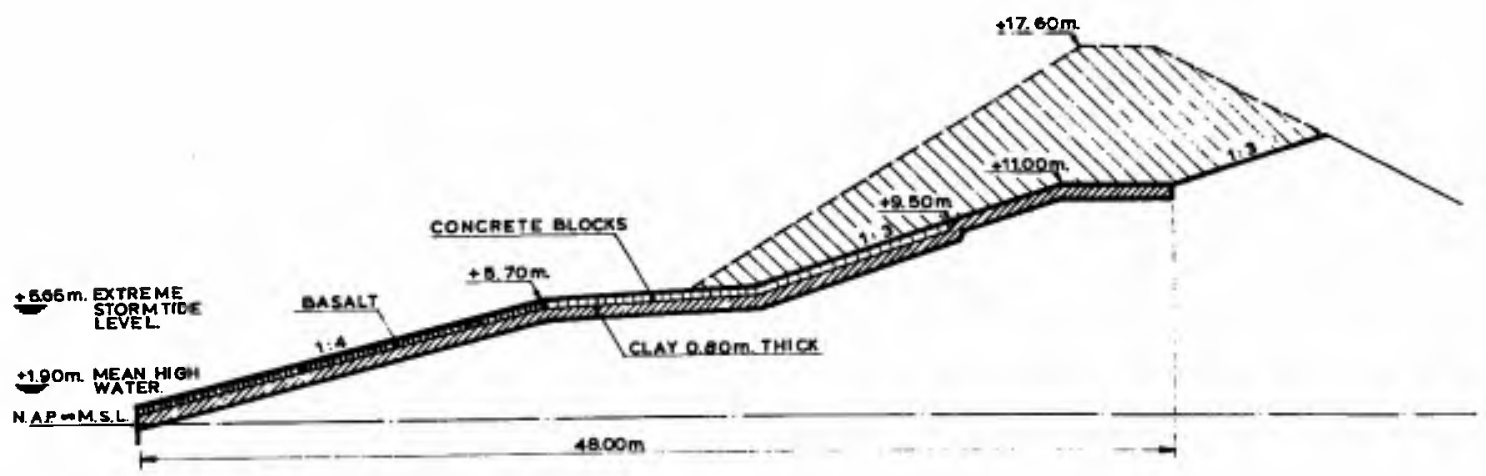

FIG. 3. REVETMENT AT ZOUTELANDE

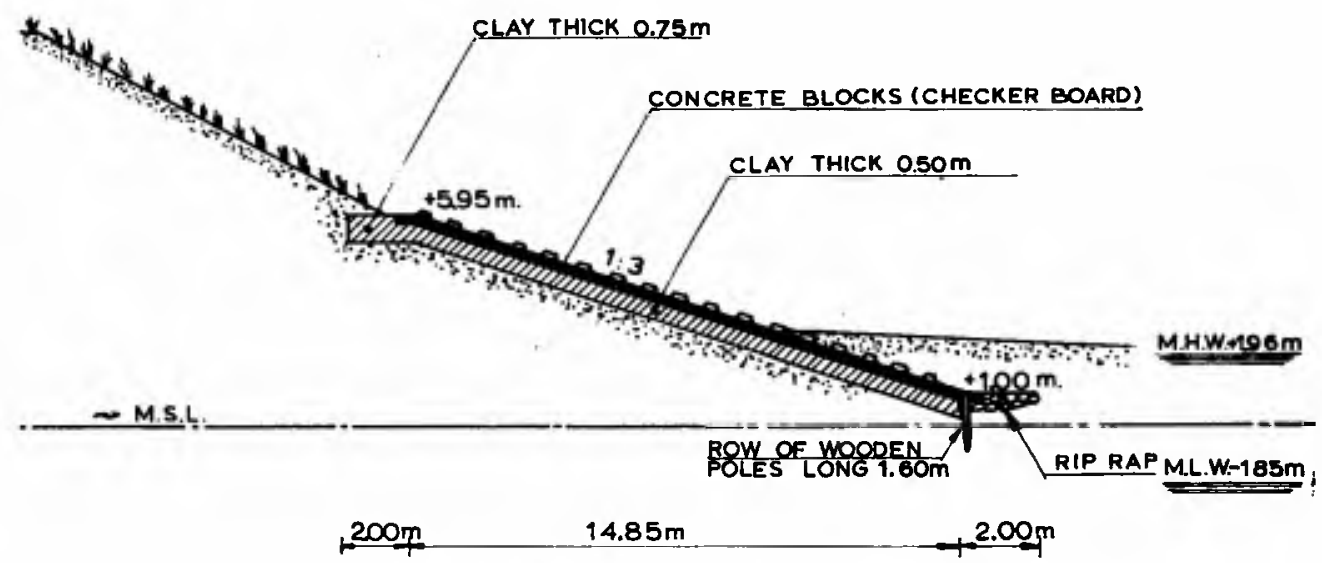

FIG. 4. REVETMENT AT BRESKENS (ZEELAND) 
This can be determined by computation or by hydraulic model experiments (16), (17).

\section{STONE PITCHING}

Revetments of natural stone have been successfully used in the Netherlands for centuries. A very traditional type is the basalt prism revetment placed on a filter construction. The latter may consist of two layers of brick (on flat side) and a layer of crushed stone or brick. Another filter consists of a layer of crushed brick, well packed, on a straw mat, fixed to the soil. The filter layer also serves to even out differences in length of the individu: pieces of rock. In earlier constructions light weight rock has sometimes been used.

An 18" - 24" basalt rock stone pitching forms a very strong revetment whis can resist heavy wave action. Small stones are sometimes keyed in between the prisms in order to increase strength of the construction.

Fig. 3 shows a cross section of a recently renewed seawal1 at Zoutelande in the province of Zeeland. The lower part of this seawall consists of a basalt prism revetment, whereas in the upper part concrete blocks have been used.

In older constructions rows of vertical poles were sometimes erected in the upper part of the slope to act as wave screen and reduce uprush. Such constructions required a great deal of maintenance whereas the effictency of such devices appeared questionable.

In a number of cases stones of larger size have been used. Compared to a basalt rock stone pitching of the same thickness the use of larger blocks does not seem advantageous since due to the larger surface area hydraulic lifting forces are greater and damage may occur easier. Here the use of a filter between the blocks and the soil is also essential to prevent wash out of soil particles.

\section{CONCRETE BLOCK REVETMENTS}

Due to shortage of skilled labor and difficulties with respect to rock supply, stone pitching revetments became too expensive.

At the same time quality of concrete blocks was gradually improving due to improvements in the manufacturing process so that at present concrete blocl of various size and shape are satisfactorily used in coastal protection for a variety of conditions.

The various types are:

(a) rectangular blocks

(b) prismatic blocks

(c) interlocking blocks of different design

(d) blocks with roughness elements of different shape 
The strength of a concrete block revetment is considerably increased if a system of interlocking is applied.

Besides the condition that individual blocks cannot easily be lifted from the construction, the shape of the joint also protects the underlying soil or filter from washing out.

In a certain instances concrete blocks have been placed on a layer of clay, without a filter (Fig. 3). This system requires accurate setting and precise dimensions of the blocks so that washout of clay particles through the joints does not occur. If such revetment is frequently attacked by waves, some washout from underneath the blocks may be experienced.

Chances for washout of particles from underneath the blocks are considerably smaller if an adequate filter is used between the blocks and the soil. For this a layer of 5 - $10 \mathrm{~mm}$ gravel of, for example, 6" - 8" thickness can be used; the size of the gravel should be small enough to prevent washout of soil particles from underneath and large enough not to pass through the joints between the blocks.

A somewhat larger type of gravel can be used if a synthetic cloth such as Filter-X is placed between the gravel and the sand, permitting that the thickness of the filter layer be cut down.

At the moment experiments are being carried out with different types of filter. In one of the tests the filter consists of broken shell on a mat of straw or reed. The tests also include the use of synthetic filter sheets.

Roughness elements on the blocks, forming a roughness pattern on the slope are beneficial in reducing wave uprush. Extensive investigations by the Delft Hydraulic Laboratory (10) have shown that reduction in run up may be of the order of $20 \%$ as compared to a smooth slope. Most effective in this respect are horizontal continuous beams or sleepers, by which a reduction of up to about $50 \%$ may be obtained. In order to be effective as a wave run-up reducing system, roughness elements or sleepers are only required on the upper part of the slope. Such elements may also be effective, however, to reduce backrush and when used on the lower part of the slope can be beneficial to prevent scour of the beach in front of the revetment. An example of this is a recently constructed revetment at Breskens (Zeeland) (Fig. 4).

\section{COPPER SLAG-BLOCK REVETMENT.}

In a few cases use has been made of copper slag-blocks for revetment construction. These blocks have a high specific weight (ab. 2.5) and demonstrate a great resistance against abrasion due to a special surface treatment with rock-split. They are placed on a filter, similar to concrete blocks and perform successfully.

Combined concrete block-copper slag-block revetment was used at the Lauwerszee-works in the northern part of Holland. Block dimensions are $0.20 \times 0.20 \times 0.33 \mathrm{~m}$.

Concrete blocks of two different heights are used in the upper part of the slope to create extra roughness. 


\section{ASPHALT GROUTED REVETMENTS}

Maintenance cost of stone pitching was greatly reduced when it became technically and economically feasible to fill the joints with asphalt bitumen. Experiments on this were started in England (Essex) just before the second world war, where asbestos fibers or sometimes sawdust were used in the compound.

A satisfactory grouting mixture consists of a hot mixture of 15-20\% asphalt bitumen $80 / 100,8 \%$ filler and $77-72 \%$ sand. The bitumen content depend on grain size and grain size distribution of the sand which is used.

Similarly asphalt grouting can also be used to fill joints between concrete blocks, whereby the upper half of the sides of the block can be recessec so as to form a wedge-formed pouring joint. In Essex standard practice since 1945 has been to use square blocks $12.5 \mathrm{~cm}$ thick and $37.5 \mathrm{~cm}$ square (14).

It should be realized that asphalt grouting in the joints may change the character of a revetment from a permeable to an impermeable type. In designir such revetment consideration should be given to the possibility of excessive hydraulic pressures as discussed earlier in this paper. Drains, therefore, may be needed and may be placed at the toe. Fig. 5 shows a revetment designer as a dune protection for the North sea coast near Den Helder (province of North-Holland). The lower part of the construction consists of an asphalt grouted basalt rock pitching. The upper part consists of asphalt. At the toe a protective apron below beach level consists of a fascine mattress weight with rock.

\section{ASPHALT REVETMENTS}

After the second world war, asphalt was to an increasing extent used in hydraulic engineering. In revetment design a great many types of constructior were built and tested, whereby the asphalt revetment developed from the test phase to a highly reliable and economic type of protection. Some of its main characteristics and requirements will be mentioned here. The material most commonly used for asphalt revetments is asphalt concrete; due to a large degr of porosity, the use of sand asphalt in earlier revetment design has been proven less satisfactory particularly below high tide level. Sea water and air penetrating into the pores finally lead to destruction of the material. Furthermore, weeds may grow through asphalt and destroy the material.

A second state in the development showed a (thick) layer of sand asphalt covered by a (thin) layer of asphalt concrete. In the tidal zone this was no completely successful. Hydraulic pressures underneath the protection could freely pass through the layer of porous sand asphalt so that the total pressure differences were to be borne by the non-porous layer of aspha1t concrete. This layer often proved to be too thin for such pressure forces so that it was lifted from its base. Another weakness was the growth of algae, etc. on asphalt surfaces in the tidal zone, causing desintegration of the asphalt from the surface downward.

In designing asphalt revetments careful consideration should be given to stability conditions of the asphalt (in various parts of the slope) and of the soil underneath as well. 

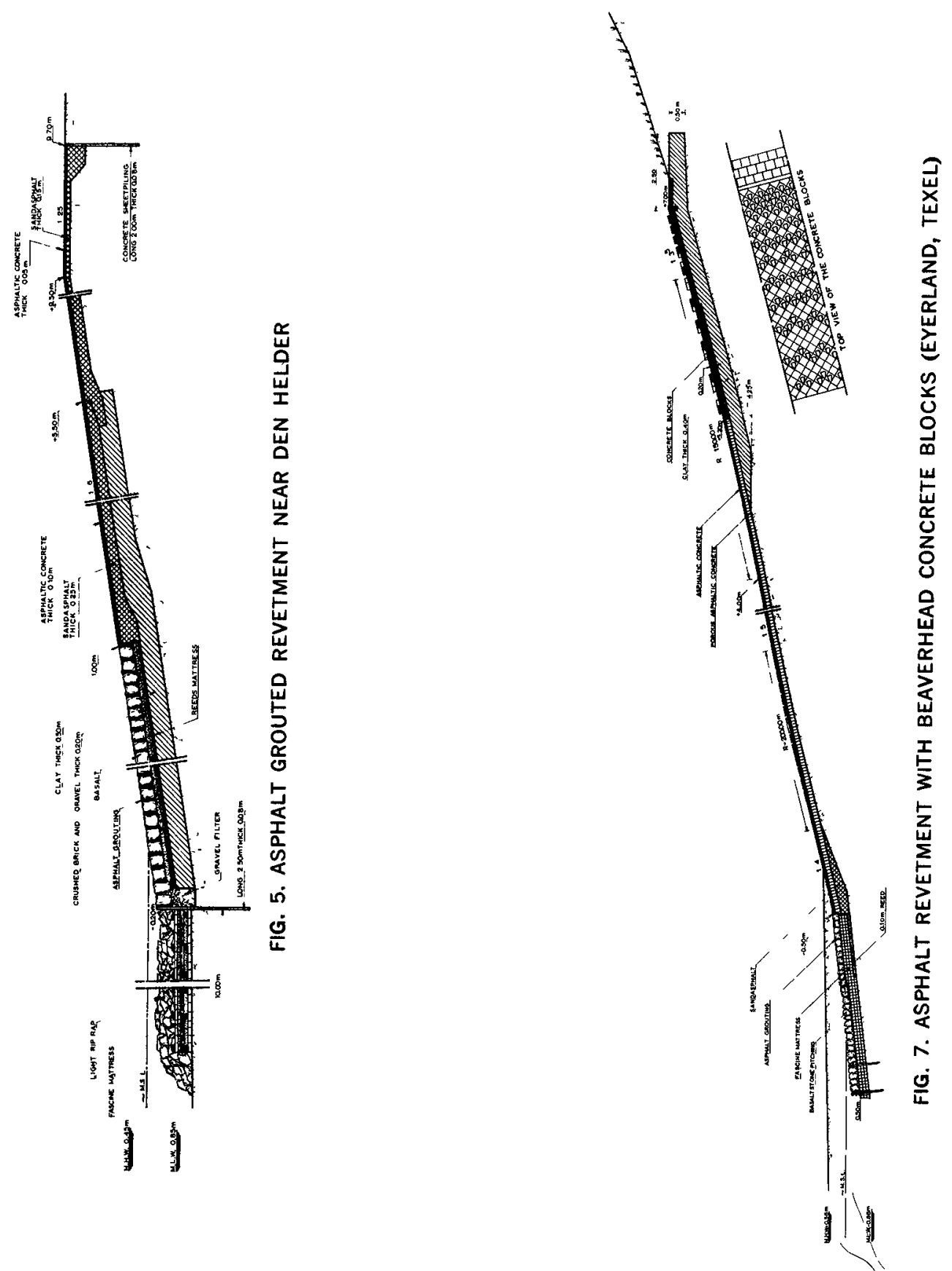


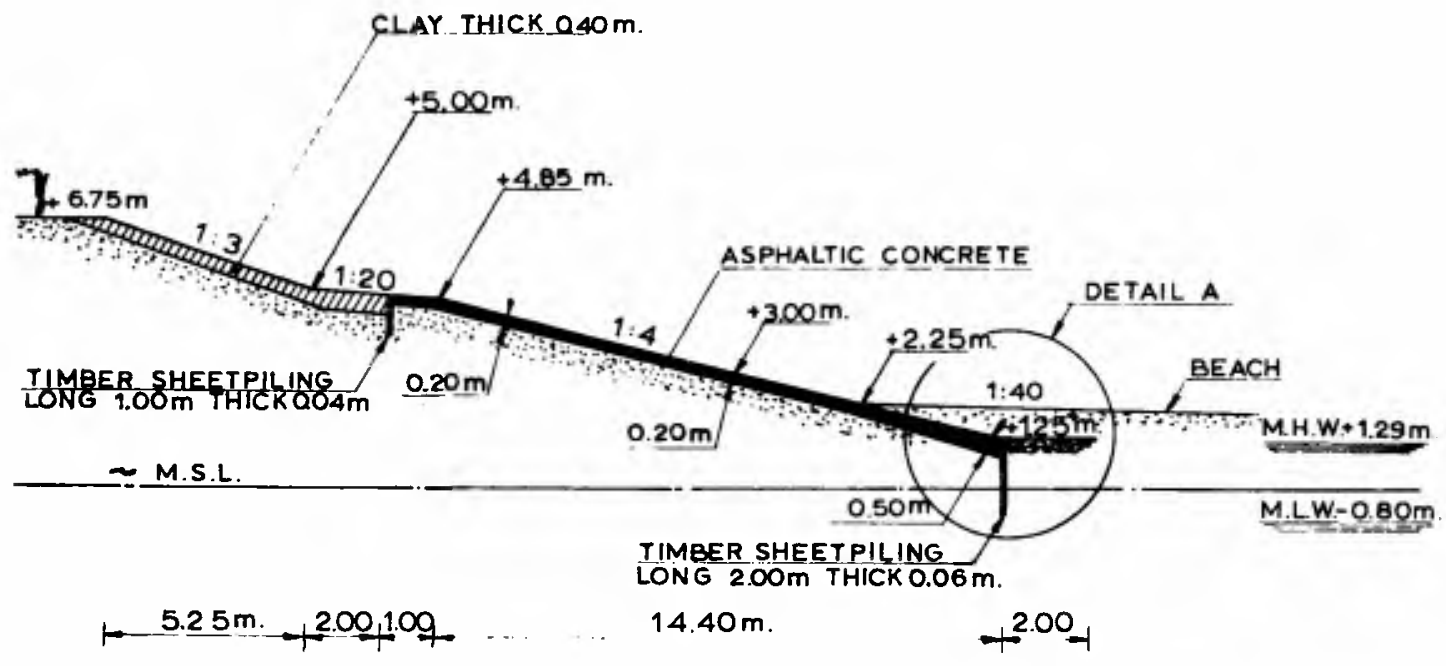

FIG. 6. ASPHALT CONCRETE REVETMENT BUILT IN DELTA AREA

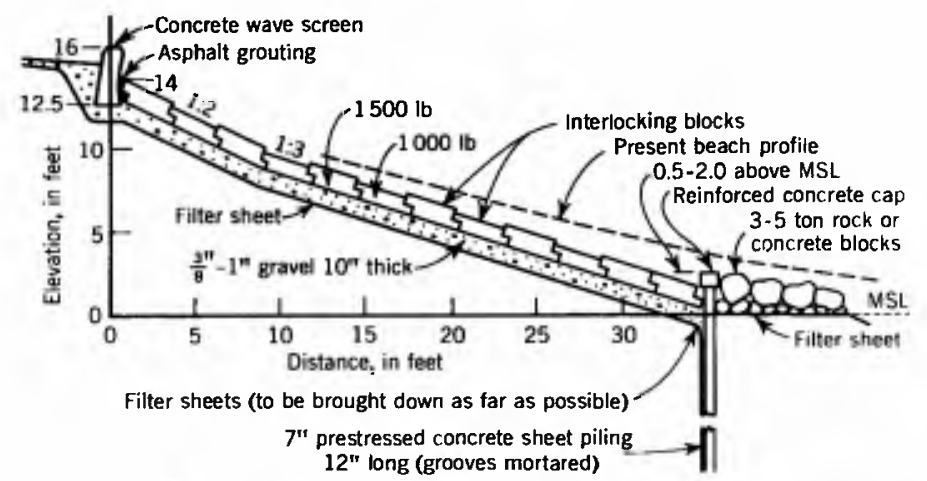

FIG. 9. INTERLOCKING CONCRETE BLOCK (“CHECKER BOARD”) REVETMENT, FLA.

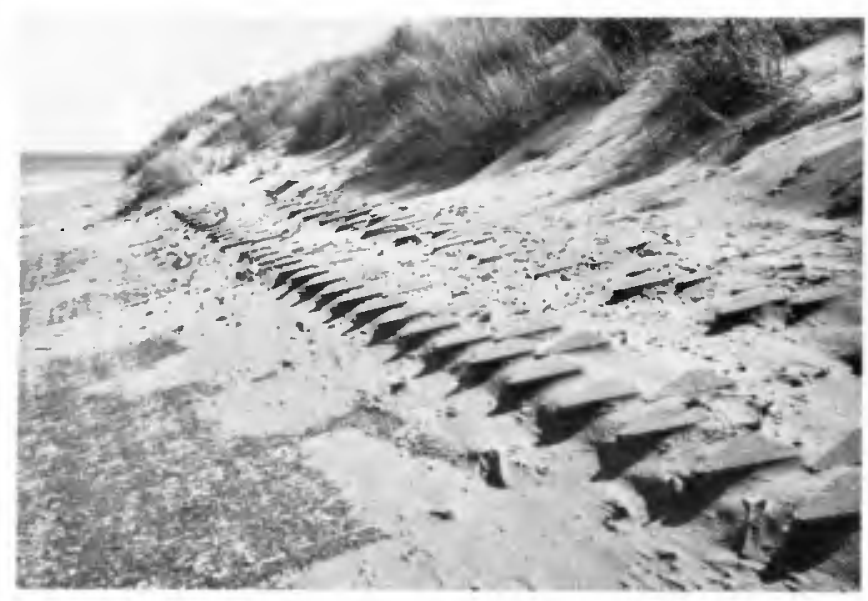

FIG. 8. SAND DEPOSITS ON REVETMENT OF FIG. 7 (TEXEL) 
At the same time drainage requirements must be carefully evaluated with respect to the type of soil that is to be protected. Two types of aspha1t can be used: cold mixtures and hot mixtures. In cold mixtures a "flux" is used to liquefy the mixture; after the flux has evaporated the asphalt becomes solid.

Hot mixtures are obtained in a plant whereby aspha1t and aggregates are heated before they are mixed. As a general rule preference is given to the hot asphalt mixture for use in coastal engineering structures. Fig. 6 shows a recently built asphalt revetment in the Delta area. General principles for this design have been the following:

a) The use of asphalt has been limited to elevations above the tida 1 zone.

b) The asphalt revetment consists of one layer of non-porous asphalt concrete of varying thickness. The mixture consists of:

$7 \%$ asphalt bitumen $80 / 100$

$7 \%$ filler

$40 \%$ graded sand

$46 \%$ crushed stone $(5-15 \mathrm{~mm})$

The maximum volume of pores is $6 \%$

c) Wave uprush should not destroy the stability of the revetment.

d) The toe consists of a tight wooden sheet piling of $2.00 \mathrm{~m}$ length and $0.06 \mathrm{~m}$ thickness.

e) A protective apron of light weight rock of about $400 \mathrm{~kg} / \mathrm{m}^{2}$ on polyaethyleen filter cloth secures stability of the toe.

f) A surface treatment is applied consisting of a hot aspha1t spray covered by sma11 size gravel.

The asphalt was put on the slope by an automatic device spreading the asphalt in the required thickness on the slope and vibrating it with a special vibrating beam. Fig. 7 shows a revetment on one of the Dutch Wadden Islands. It was constructed on the northern tip of Texel, where erosion of the dunes had been very heavy during a number of years.

The lower part of the revetment consists of an asphalt slope protection; on the upper part concrete blocks, some of them provided with beaverhead shaped roughness elements, have been used.

The pattern of the roughness elements was investigated by hydraulic model tests, so as to find its greatest effectiveness.

The roughness elements proved very successful in working as sand trap for material transported by wind (Fig. 8).

A recent1y developed aspha1t revetment consists of hot aspha1t concrete and rock, thoroughly mixed and put on a filter. For the latter a layer of 
minestone has been used.

The properties of this type of construction are still being studied. Compared to the asphalt grouted stone revetment, the aspha1t rock is cheaper because it contains less bitumen per unit of volume. Other features are a higher permeability and rougher surface. The question of durability is being studied.

\section{AMERICAN PRACTICE WITH SPECIAL REFERENCE}

\section{TO FLORIDA CONDITIONS}

Granite revetments have been built in the United States as rough as wel1 as smooth glacies, but practice has mainly been restricted to areas where granite was easily available as, for example, in the New England states and in the State of California. Granite blocks were carefully placed on gravel filters. Concrete structures of revetment nature, although not always fulfilling the requirement of energy-absorbing ability, are found, for example, in the San Francisco Explanada seawal1, in the stepped wall at Corpus Christi, Texas, and in the smooth-faced at Pioneer Point, Maryland. The numerous cana 1 linings and river slope protections in the Mississippi valley are also of reve ment type. New developments of revetments have taken place in Florida in recent years comprising permeable limestone (local rock) as we11 as permeable interlocking concrete block designs (15). The former consists of local rock placed on minor rock and gravel which rests on synthetic filter sheets of Poly-Filter $x$ type.

Fig. 9 is cross section of an interlocking block revetment of the type built at Jupiter Island, Fla. All measures refer to this particular location. Figs. 10 and 11 present interesting comparisons between the function of such energy absorbing structure and a vertical wall during a storm situation (March 9-10, 1962). It is clear that the revetment is preserving while the vertical wa11 is destructive.

This revetment consists of a toe protection of $7 \mathrm{in}$. reinforced tongue ar groove sheet pane1s. They are $2 \frac{1}{2} \mathrm{ft}$ wide and $12 \mathrm{ft}$ long and are capped by reinforced concrete at 0.5 to $2.0 \mathrm{ft}$ above M.S.L. A heavy toe protection of 3-5 $t$ rock (specific welght as high as possible) or of concrete blocks shou] be placed in front resting on filter sheets. If only smaller blocks are avail able, asphalt grouting may be used. Slope protection consists of a $1: 3$ inter. locking block layer, $3^{\prime}$ square by $10^{\prime \prime}$ thick in two $5^{\prime \prime}$ sections with $5^{\prime \prime}$ offset on two sides to allow interlocking. In order to provide friction to wave uprush, every second block has a $9^{\prime \prime}$ top layer $\left(5^{\prime \prime}+4^{\prime \prime}\right)$ which increases the total weight from approximately $1,000-1,100$ 1bs to $1,500-1,600$ 1bs. These blocks are cast in a continuous pour with no seams. Immediately after the concrete has been poured, a reinforcing rod is placed in the block supported by wooden blocks to be removed later. This allows the dragline hook to be fastened to 1ift and place the block during construction. Above elevation 10 the slope is $1: 2$ up to elevation $+14^{\prime}$ where a concrete wave screen (of varyin design and top elevation) finish the protection upwards. Oversplash behind the wave screen may occur and justifies a gravel filter blanket behind the wave screen. The highest row of blocks is grouted with asphalt where it join the wave screen. 


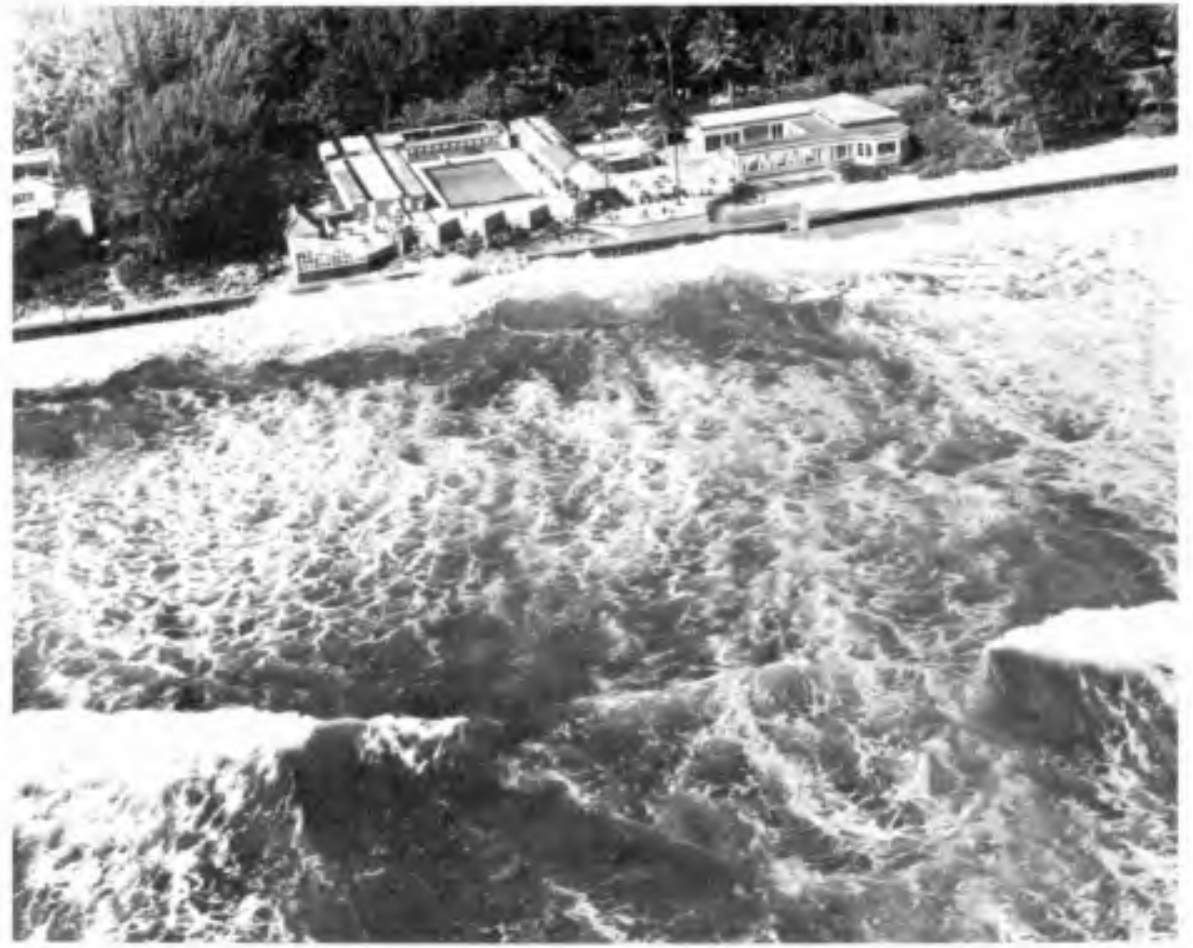

FIG. 10. WAVE ACTION ON VERTICAL (STEEL SHEET PILE) WALL, JUPITER ISLAND, FLA.

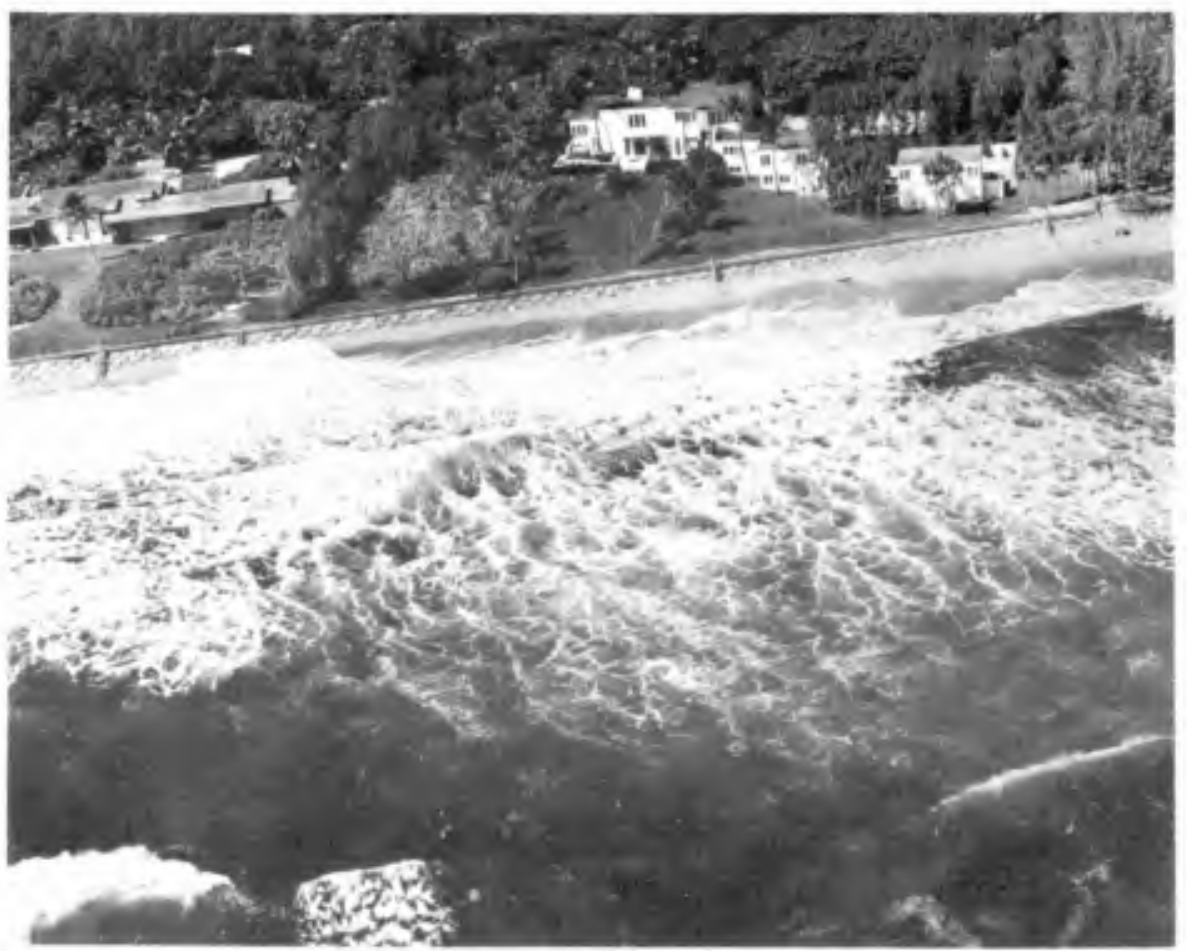

FIG. 11. WAVE ACTION ON CHECKER-BOARD REVETMENT, JUPITER ISLAND, FLA. 
The interlocking blocks rest on a filter layer consisting of Filter-X with $3 / 16^{\prime \prime}$, $15^{\prime \prime}$ stee1 securing pins provided with our staked "ears" to increase holding power and a $\frac{1}{2} "$ diameter metal washer. Overlapping is $8^{\prime \prime}$. An 8 to $10^{\prime \prime}$ layer of crushed hard rock 3/8-1 in. is placed on the top of the synthetic filter. This filter is carried down behind the toe sheet as deep as practically possible depending upon the permeability of the tongue and groove installation. With double groove panels with proper rellable grouting, this is less important. Florida contractors recommend a minimum depth of $5^{\prime}$ below M.S.L. for the filter. Filter sheets are also carried up below and behind the wave screen.

Most important are the returns which often present the weak point of such design. Panels similar to those used for the toe should also be used for the returns. Length of panels may be $12^{\prime}$ until halfway up the revetment, then increased to $16^{\prime}$ for the remainder of the slope. As a matter of safety against back scours, the returns should be carried well behind the top of the revetment--the actual length depending upon the local situation. The returns should also be lined with filter sheets. The outside of the return should be protected by placing heavy (1-3 t) rubble on filter sheets of the newly invented Poly-Filter $X$ type extending beyond the entire length of the slope. Asphalt grouting and smaller rock may be used too, if necessary.

Under normal conditions, it will be little or no maintenance on such revetment. Minor sinking may occur. During storms damage to toe-protection and return-protection may take place and repairs by replenishments may have to be done. In case breaks should occur in the revetment itself, for example, because a heavy piece of lumber hit the revetment, emergency repairs using filter sheets and rubble are indispensable to avoid that damage spreads to al1 sides. In a high permeability soil some minor sinking of blocks may take place.

It is obvious that practical and economic considerations will have to be joined in harmony to secure for practical purposes an adequate design. The strongest block is the heaviest and the most expensive one. Special block geometry may decrease uprush height but increase cost of production and construction, etc. So far, the squared checker-board blocks have the advantage of being easy to make and easy to place but uprush height can, needless to say, be decreased by a stepped block. In an estuary boat waves may be important and heavy single wave uprush has to be decreased as much as possible On a seashore, economy may often call for simplicity rather than for top p erformance hydraulically speaking. The checker-board blocks still seem to have a high grade performance and the best economy but they must be adjusted to meet the local wave and beach situation. Bids on more complex blocks have not justified the use of them as replacement for the squared checker-board block on dune slopes.

\section{REFERENCES}

(1) Schijf, J. B. "Generalities on Coastal Processes and Protection", Journa1, Waterways and Harbors Division, Proceeding A.S.C.E., March, 1959.

(2) Bruun, P. "Use of Sma11 Scale Experiments with Equilibrium Profiles in Studying Actual Problems and Developing Plans for Coastal Protection' Trans. Amer. Geophys. Union, Vo1. 35, No. 3, June, 1954. 
(3) Wemelsfelder, P. J. "Wetmatigheden in het optreden van stormvloeden", De Ingenieur, No. 9, 1939.

(4) Report of the Delta Committee. Parts 1 through 6. Final Report and Interim Reports. Staatsdrukkerij- en Uitgeverijbedrijf - 's-Gravenhage, 1960.

(5) Bruun, P.; Chiu, T. Y.; Gerritsen F, and Morgan, W. H. "Storm Tides in Florida as Related to Coastal Topography", Engineering Progress at the University of Florida, Vol. XVI, No. 1, Jan., 1962.

(6) Bretschneider, C. L. "Revision in Wave Forecoasting - Deep and shallow Water", Coastal Engineering, Council on Wave Research, University of California, Berkeley, Vol. 6, pp 30-67, 1957.

(7) Wilson, B. W. "Deep Water Wave Generations by Moving Wind Systems", Journal, Waterways and Harbors Division, A.S.C.E., New York, Vo1. 87, No. Ww2, pp. 113-141, May, 1961 .

(8) Committee on Impervious S1opes; Progress Report, Rijkswaterstaat, The Netherlands, 1961.

(9) Bruun, P. "Breakwaters for Coastal Protection", XVIIIth Int1. Navigation Congress, Rome, 1953.

(10) Wassing, F. 'Mode1 Investigation of Wave Run Up on Dikes Carried Out in the Netherlands During the Past Twenty Years", Coasta1 Engineering No. VI, Council on Wave Research, University of California, Berkeley, Part IV, PP. 700-714, 1958.

(11) Savage, R. P. "Wave Run Up on Roughned and Permeable Slopes", Proceedings Waterways and Harbors Division, A.S.C.E. New York, Vo1. 84, No. WW 3, 38 pp., 1958.

(12) Bischoff van Heemskerck, W. C. "Water Pressures Underneath Asphalt Revetments", Vereniging voor Bitumineuze Werken, The Hague, 1962.

(13) Carlson, E. J. "Gravel Blanket to Prevent Wave Erosion", Journa1 of the Hydraulics Division, Proceedings, A.S.C.E., Vol. 85, No. HY 5, May 1959.

(14) Asbeck, W. F. van "Bitumen in Hydraulic Engineering", Shell Petroleum Corp. Ltd. , London, 1955.

(15) Bruun, P. and Manohar, M. "Coasta1 Protection for F1orida: Development and Design, with Appendix by F. Gerritsen", Engineering Progress at the University of Florida, Vol. XVII, No. 8, August, 1963.

(16) Brandtzaeg, A. "A Simple Mathematical Model of Wave Motion on a Rubble Mound Breakwater Slope", Coastal Engineering No. XIII, Council on Wave Research, University of California, Berkeley, 1963, pp. 444-468.

(17) Hudson, R. Y. "Laboratory Investigations of Rubble Mound Breakwaters", Trans. A.S.C.E., Vo1. 126, 1961, Part IV, p. 491. 